\title{
Population Dynamics of Cotton Jassid (Amrassica Biguttula) in Relation to \\ Weather Parameters in Multan
}

\section{Ghulam Murtaza ${ }^{2}$, Muhammad Ramzan ${ }^{1 *}$, Unsar Naeem-Ullah ${ }^{1}$, Mirza Abdul Qayyum ${ }^{1}$, Ahmad Nawaz ${ }^{2}$, Umair $^{2}$ Rasool Azmi ${ }^{3}$ and Muhammad Ali ${ }^{1}$}

1Department of Entomology, Muhammad Nawaz Shareef University of Agriculture, Multan, Pakistan

${ }^{2}$ Department of Entomology, University of Agriculture, Faisalabad, Pakistan

${ }^{3}$ Department of Plant Breeding and Genetics, University of Agriculture, Faisalabad, Pakistan

*Corresponding Author: Muhammad Ramzan, Department of Entomology, Muhammad Nawaz Shareef University of Agriculture, Multan, Pakistan

Received: July 02, 2019; Published: July 29, 2019

DOI: $10.31080 / A S A G .2019 .03 .0588$

\begin{abstract}
Cotton (Gossypium hirsutum L.) is one of the important crops globally named as white gold. In Pakistan, it is one of the major cash crops. However, cotton production is not being increased within the several years. It is mainly because of being attacked by the sucking insect fauna especially by the cotton Jassid. Thus, the present experiment was conducted to know about the seasonal fluctuation of Jassid. Data was recorded from May - December in Multan, 2017. During the study, Jassid population was noted on two genotypes,Bt (MNH-992) and non-Bt (Cyto-124). The impact of weather parameters like temperature, humidity and rainfall on cotton jassid was recorded. The results revealed that the minimum population of Jassid was observed on2nd week of May and the pest population was 0.83-1.20/3 leaves, while the maximum population was recorded during the 1 st week of September i.e. Bt ( $9.96 / 3$ leaves) and non-Bt (6.40/3 leaves) respectively. The correlation of Jassid population showed significant effect with the temperature and rainfall, while the relative humidity has non-significant effect. Thus, it can be concluded that the climate change has prominent effect on the Jassid population.
\end{abstract}

Keywords: Cotton Jassid; Temperature; Humidity; Rainfall; Multan

\section{Introduction}

Cotton (Gossypium hirsutum L.,) is an important crop and globally named as white gold. The economy of Pakistan is mostlydepending on the agriculture and its products. According to economic survey, cotton itself contribute 7-10\% value added to agriculture (Anonymous, 2012-13). Pakistan is the $4^{\text {th }}$ largest cotton producing country in the world, as an exporter of raw cotton and ranks $3^{\text {rd }}$ in number. Cotton is cash crop,susceptible to the attacked by various type of insect pest like sucking as well as chewing, which lead to significant reduction of cotton production $[1,2]$.

Among them, sucking insect pests like Thrips (Thrips tabaci (Lind), whitefly (Bemisia tabaci (Genus) and jassid (Amrasca biguttula biguttula) are major threat to cotton industries in all over the world [2-4]. The quality as well as quantity in the form of yield and production of cotton reduce due to severe attack of sucking insect pests $[3,5-7]$.
Among the sucking insect pests, jassid is the major threat for cotton growing areas of the world including Pakistan [8,9]. The pear shaped, yellowish white and elongated eggs laid by A. biguttula biguttula on the upper leaf surface of plants. Nymphs are whitish-pale-green, wingless while adults are pale green, wedgeshaped and 2 to $3 \mathrm{~mm}$ long in size. About 15-29 eggs laid by female. Female prefer to lay eggs on mature leaves. Nymphal and adult period last for 7 to 21 days and 5 to 8 weeks, respectively. There are 10 to 12 generations of jassid per year. Within 15-46 days life cycle is completed. Adult and nymph, both suck the cell sap from the plants twigs and leaves, which directly affect the photosynthetic mechanism of plants and resulting the reduction of the boll formation. Approximately 19.0\% cotton yield is reduced due to Jassid infestation [10]. The mosaic virus disease is spread during severe attack of jassid [11].

Furthermore, other weather parameters like rainfall, humidity and temperature play a remarkable part in the expansion, occurrence and population alteration of sucking insect pests throughout 
the cotton season [12-14]. The weather parameters like humidity and temperature also fluctuate the jassid population [9,15]. The jassid populations have significant positive association with temperature while negative with rainfall and humidity was non-significant Ali., et al. [10].

The excessive use of insecticides for the prevention of crops from the attack of these pests, caused resistance in pests. Not only cause resistance but also become major problem for environmental pollution [2] and harmful for natural enemies such as biological fauna. The current study was carried out to study the pest population and also provide information about the relationship of pest with weather parameters like temperature, humidity and rainfall. Information on weather parameters will help the entomologists and policy makers to take up an effective decision for (IPM) pests management strategies.

\section{Materials and Methods \\ Experiment Site}

The experimental study was conducted at Research Farm of Muhammad Nawaz Shareef University of Agriculture, Multan during the cropping season 2017. To check the effect of abiotic factors on the jassid population, two cotton verities, Bt (MNH - 992) and NonBt (Cyto - 124) were sown by using Randomize complete block design (RCBD) with four replications. Entire filed was divided into eight blocks, and block size (25 - 26 sq. feet) with distance $(\mathrm{P} \times \mathrm{P}$ $\left.=9^{\prime \prime}\right)$ and $\left(\mathrm{R} \times \mathrm{R}=2 \cdot 5^{\prime \prime}\right)$.The geographic site of experiments was $30.1575^{\circ} \mathrm{N}$ Latitude, $71.5249^{\circ} \mathrm{E}$ Longitude and Elevation above sea level $129 \mathrm{~m}$ or $423 \mathrm{ft}$. No insecticide was sprayed during the whole study to allow cotton jassid to multiply. During the whole cropping duration, all recommended agronomic practices were applied for rising the crop production.

\section{Data recording}

Population of cotton jassid was recorded weekly basis on randomly selected plants leave sat early morning (7:00 am) from May to December 2017. Thirty different plants leaves were randomly selected from individual plot, counted the jassid number either adults and nymphs from upper, middle and lower leaves of first, second and third plant, respectively. In addition, during the study climatic factors viz. total rainfall, temperature and humidity were also documented. The weekly basis weather data obtained from Metrological Department of Central Cotton Research Institute, Multan, Pakistan.

\section{Statistical analysis}

The recorded data was statistically analyzed by using the analysis of variance in "Statistix v8.1" (Analytical Software, 2005) and through least significant difference test (LST) $(\alpha=0.05)$ treatment significance was determined to separate the means (Khan., et al. 2012).

\section{Results}

\section{Jassid population}

Jassid is key sucking pest of cotton, observed throughout the crop season from May-December 2017. The study revealed thatcotton jassid population was lowest ( $0.83-1.20 / 3$ leaves) at early stage of cotton while cross the thresh hold level from September to October. The cotton jassid population was highest on Bt cotton compared to non-Bt.The maximum population ( $>1$ 2.03/3 leaves) were found during the 2nd week of September on Bt and(9.96/3 leaves) on non Btwhile minimum population (6.40/3 leaves) was recorded on Bt and non Bt (3.56/3 leaves) genotype. The jassid population was found high (6.76/3 leaves) in last week of August. The study showed that Jassid population remains above the Economic Threshold Level (ETL) throughout the study duration except in month of July.

\section{Correlation of jassid population with weather parameters}

The weather parameters like humidity, temperature and rainfall were helpful for the jassid population. During the whole study maximum temperature and humidity was $30-37.90 \mathrm{C}$ and $77.6 \%$, respectively while $20-23.2^{\circ} \mathrm{C}$ was minimum. However, jassid population was maximum at $30.90 \mathrm{C}$ temperature and $76.6 \%$ relative humidity (RH).

The results showed that the cotton jassid population has positive correlation with temperature and negative non-significance correlation with the morning and evening relative humidity. It was observed that the population of jassid abruptly build up after the rainfall so, humidity is favorable for jassid growth and development. The study revealed that rainfall, humidity and temperature have a significant role for the incidence of jassid population.

\section{Discussion}

The results of current study are similar with Bishnol., et al. [16] who reported that jassid population have positive correlation with weather parameters like humidity and temperature. The similar findings recorded by Ei-Mezayyen., et al. (1997) that pest population is greatly affected by temperature and relative humidity. Our study results are agreements with the results of Majeed., et al. [17] that weather parameters are influenced the jassid population.

Our results are same as Shitole and Patel (2009), Kaur., et al. (2009), Prasad., et al. [18], Dhaka and Pareek [19], Ramamurthy., et al. [20] and Rao., et al. (2001), reported that the maximum temperature had a non-significant and negative association with jassid population. Kavitha., et al. [21], Singh., et al. [22], Aheer., et al. [12], Shitole and Patel (2009) and Selvaraj., et al. [23] observed that minimum temperature and rainfall had negative association with jassid population. Nemade., et al. [24], Kavitha., et al. [21] and Sewasingh., et al. (2004) reported that rainfall and temperature had positive correlation with jassid population. Our observations with respect to rainfall are different from Mahmood., et al. [25]. 
According to Mahmood., et al. [25] extreme temperature has optimistic correlation while humidity and rainfall has adverseresult on cotton jassid. The evening relative humidity and rainfall was positively correlated with cotton jassid as reported by Soujanya., et al. [26].

During the study maximum and minimum temperature was $30-39^{\circ} \mathrm{C}$ and 20 to $23.5^{\circ} \mathrm{C}$, respectively. The similar results about temperature have been recorded by Prasad., et al. [18] and Kaur., et al. (2009). Abdullah [27] and Mohapatra (2008) stated that the pest population was high in the months of September and August, respectively and is similar to our findings. The study reported that number of jassid were high in last week of august which is similar to Abro., et al. [28] and Solangi., et al. [29] studies. The warm and humid condition in these months is the main reason of high population. The pest population was high in the first week of August and continue to decrease in the last week of October as stated by Shad., et al. [30], Khan and Ullah [31] and Gupta., et al. [8].

\section{Conclusion}

The purpose of current study was to check the jassid population on cotton with relation to weather parameters like temperature, humidity and rainfall. Present work concludes that cotton jassid was found high on Bt. Cotton. Among weather factors humidity, temperature and rain fall play the significant role in population fluctuation of leaf miner on cotton crop [32-38].

\section{Acknowledgement}

Authors are thankful to MNS-University of Agriculture, Multan especially Department of Entomology for their assistance and sustenance during the research work.

\section{Bibliography}

1. Arshad M., et al. "Estimation of useful heterosis in interspecific F1 cotton hybrids". Journal of Agricultural Research 4.1 (2001): 65-67.

2. Salman M., et al. "The resistance levels of different cotton varieties against sucking insect pests complex in Pakistan". Pakistan Journal of Agriculture, Agricultural Engineering and Veterinary Sciences 27.2 (2011): 168-175.

3. Arif Muhammad Jalal., et al. "Impact of plant spacing and abiotic factors on population dynamics of sucking insect pests of cotton". Pakistan Journal of Biological Sciences 9.7 (2006): 1364-1369.

4. Ali A and GM Aheer. "Varietal resistance against sucking insect pests of cotton under Bahawalpur ecological conditions [Pakistan]". Journal of Agricultural Research (Pakistan) (2007).
5. Khan Muhammad Ahsan., et al. "Incidence and development of Thripstabaci and Tetranychusurticae on field grown cotton". International Journal of Agriculture and Biology 10 (2008): 232-234.

6. Amin MR., et al. "Characteristics of some cotton varieties in relation to seasonal abundance of pests, predators and their impact on yield and quality". Journal of agroforestry and environment 2.2 (2008): 67-70.

7. Shah Syed Ishfaq Ali. "The cotton stainer (Dysdercuskoenigii): An emerging serious threat for cotton crop in Pakistan". Pakistan Journal of Zoology 46.2 (2014).

8. Gupta MP., et al. "Population build-up of some sap sucking insects on cotton in Madhya Pradesh". Journal of Insect Science 10.2 (1997): 153-156.

9. Inee Gogoi and BC Dutta. "Seasonal abundance of cotton jassid, Amrascabiguttulabiguttula (Ishida) on okra". Journal of the Agricultural Science Society of North-East India 13.1 (2000): 22-26.

10. Ali A., et al. "Role of weather in fluctuating the population of Amrascadevastans (Dist.) and Thripstabaci (Lind.)". Proceedings of Pakistan Congress of Zoology 13 (1993): 133-139.

11. Samal T and HP Patnaik. "Field efficacy of Insecticides against Amrascabiguttulabiguttula (Ishida) incidence on Egg plant”. Annals of Plant Protection Sciences 16.1 (2008): 115-118.

12. Aheer GM., et al. "Role of weather in fluctuating aphid density in wheat crop". Journal of Agricultural Research (Pakistan) (1994).

13. Mohapatra LN. "Population dynamics of sucking pests in hirsutum cotton and influence of weather parameters on its incidence in western Orissa". Journal of Cotton Research and Development 22.2 (2008): 192-194.

14. Akram Muhammad., et al. "A case to study population dynamics of Bemisiatabaci and Thripstabaci on Bt and non-Bt cotton genotypes". Pakistan Journal of Agricultural Sciences 50.4 (2013).

15. Sharma GN and PD Sharma. "Population dynamics of cotton leaf hopper, Amrascabiguttulabiguttula (Ishida) on cotton and okra in relation to the physical factors of environment in Haryana". Annals of Biology 13 (1997): 189-184.

16. Bishnoi OP., et al. "Population dynamics of cotton pests in relation to weather parameters". Indian Journal of Entomology 58.2 (1996): 103-107. 
17. Majeed Muhammad Zeeshan., et al. "Population dynamics of sucking pest complex on some advanced genotypes of cotton under unsprayed conditions". Pakistan Journal of Zoology 48.2 (2016).

18. Prasad NVVSD., et al. "Population dynamics of major sucking pests infesting cotton and their relation to weather parameters". Journal of Cotton Research and Development 22.1 (2008): 85-90.

19. Dhaka Shish Ram and Bhanwar Lal Pareek. "Seasonal Incidence of Natural Enemies of Key Insect Pests of Cotton and Their Relationship with weather Parameters". Journal of Plant Protection Research 47.4 (2007).

20. Ramamurthy R., et al. "Impact of weather parameters on cotton pests". Journal of Cotton Research and Development 14.2 (2000): 193-195.

21. Kavitha G., et al. "Arthropod predatory fauna and its population dynamics in cotton in Haryana". Journal of Cotton Research and Development 17 (2003): 167-171.

22. Singh Jagdev and NS Butter. "Influence of climatic factors on the buildup of whitefly BemisiatabaciGenn on cotton". Indian journal of entomology (1985).

23. Selvaraj S., et al. "Population dynamics of leafhopper, Amrascadevastans Distant in Cotton and its relationship with weather parameters". Journal of Entomology 8.5 (2011): 476-483.

24. Nemade Prashant W., et al. "Population Dynamics of Sucking Pests with Relation to Weather Parameters in Bt Cotton in Buldana District, Maharashtra, India". International Journal of Current Microbiology and Applied Sciences 7.1 (2018): 620-626.

25. Mahmood Tariq., et al. "Population dynamic of leaf hopper (Amrascabiguttulabiguttula) on brinjal and effects of abiotic factors on its dynamics". Asian Journal of Plant Sciences (2002).

26. Soujanya PL., et al. "Population dynamics of sucking pests and their relation to weather parameters in Bt, stacked Bt and non Bt cotton hybrids". Trends in Biosciences 3.1 (2010): 15-18.

27. Abdullah Ahsan. "An analysis of Bt cotton cultivation in Punjab, Pakistan using the agriculture Decision Support System (ADSS)". (2010).

28. Abro GH., et al. "Performance of transgenic Bt cotton against insect pest infestation”. Biotechnology 3.1 (2004): 75-81.
29. GS Solangi., et al. "Presence and abundance of different insect predators against sucking insect pest of cotton". Journal of Entomology 5.1 (2008): 31-37.

30. Shad SA., et al. "Relative response of different cultivars of cotton to sucking insect pests at Faisalabad". Pakistan Entomological 23.1-2 (2001): 79-81.

31. Khan SM and Z Ullah. "Population dynamics of insect pests of cotton in Dera Ismail Khan [Pakistan]". Sarhad Journal of Agriculture (Pakistan) (1994).

32. Azam Anam and Muhammad Shafique. "Agriculture in Pakistan and its Impact on Economy. A Review". International Journal of Advanced Science and Technology 103 (2017): 4760.

33. Bhat MG., et al. "Relative loss of seed cotton yield by jassid and bollworms in some cotton genotypes (Gossypium hirsutum L.)". Indian Journal of Entomology (1984).

34. Fiaz Muhammad., et al. "Efficacy of plant extracts on some cotton (Gossypium hirsutum) pests: Amrascabigutullabigutulla Ishida and Thripstabaci Lindeman". Pakistan Journal of Zoology 44.1 (2012).

35. Muhammad Rafiq., et al. "Population dynamics of whitefly (Bemisiatabaci) on cultivated crop hosts and their role in regulating its carry-over to cotton". International Journal of Agriculture and Biology 10.5 (2008): 577-580.

36. Prabhjyot Kaur., et al. "Formulation of weather-based criteria rules for the prediction of sucking pests in cotton (Gossypium hirsutum) in Punjab". Indian Journal of Agricultural Sciences 79.5 (2009): 375-380.

37. Sarwar Muhammad., et al. "Identification of resistance to insect pests infestations in cotton (Gossypium hirsutum L.) varieties evaluated in the field experiment". International Journal of Scientific Research in Environmental Sciences 1.11 (2013): 317.

38. Solangi BK., et al. "Population of Spotted Bollworm Earias spp. and Its Predators (Natural Enemies) on Cotton". Journal of Applied Sciences 5.8 (2005): 1402-1404.

\section{Volume 3 Issue 8 August 2019}

(C) All rights are reserved by Muhammad Ramzan., et al. 